\title{
A Review of Considered Factors to Penetrate Renewable Energy Resources in Electrical Power System
}

\author{
Dhanis Woro Fittrin Selo Nur Giyatno ${ }^{*}$ \\ a Universitas Gadjah Mada, Grafika 2, Yogyakarta, Indonesia \\ email : woro_s2te_11@mail.ugm.ac.id
}

\begin{abstract}
As an increasing of load demand, scarcity of fossil fuel and penetration of greenhouse gasses (GHG) effect, utilization of renewable energy resources (RER) such as wind, solar, biomass and tidal are rising drastically. Distributed generation (DG) is a technology giving opportunity to integrate RER into power system network. These integrations are needed optimal long term planning. Those planning, hopefully, can increase reliability of electrical power system network while saving environment from GHG with minimum infestation, operation and maintenance cost. The aim of this paper is reviewing factors should be consider when preparing, operating and evaluating electrical power system with integration of RER. By this planning, it is expected that its integration is effective and efficient in a lifetime of project. Finally, this review can help government, researcher, engineer and private sector to make policies to preparing hybrid power system-DGs.
\end{abstract}

Keywords: Penetration of renewable energy resources, electrical power system, long term planning, distributed generation, policies

$\begin{array}{ll}\text { Nomenclature } \\ \text { GHG } & \text { Greenhouse Gas } \\ \text { RER } & \text { Renewable Energy Resource } \\ \text { DG } & \text { Distributed Generation } \\ \text { GEP } & \text { Generation Expansion Planning } \\ \text { PSO } & \text { Particle Swarm Optimization } \\ \text { GA } & \text { Genetic Algorithm } \\ \text { EPSO } & \text { Evolutionary Particle Swarm Optimization } \\ \text { REPSO } & \text { Rank of Evolutionary Particle Swarm } \\ & \text { Optimization } \\ \text { IPSO } & \text { Iterative Particle Swarm Optimization } \\ \text { CRPSO } & \text { Craziness based Particle Swarm } \\ & \text { Optimization } \\ \text { NSGA-II } & \text { Non-dominated Sorting } \\ & \text { Algorithm-II Genetic } \\ \text { IAGA } & \text { Improve Adaptive Genetic Algorithm } \\ \text { AGA } & \text { Adaptive Genetic Algorithm } \\ \text { QGA } & \text { Quantum Genetic Algorithm } \\ \text { ANOVA } & \text { Analysis of Variants } \\ \text { T2FBPSOM } & \text { Type 2 Fuzzy Binary Particle Swarm } \\ & \text { Optimization Modified } \\ \text { HBMO } & \text { Honey Bee Mating Optimization } \\ \end{array}$

$\begin{array}{ll}\text { DFIG } & \text { Doubly-fed Induction Generator } \\ \text { SVR } & \text { Support Vector Regression } \\ \text { ANN } & \text { Artificial Neural Network } \\ \text { BP } & \text { Back Propagation } \\ \text { CBA } & \text { Cost Benefit Analysis } \\ \text { GENCO } & \text { Generation Companies } \\ \text { IRR } & \text { Internal Rate of Return } \\ \text { CD } & \text { Community Development } \\ \text { CDM } & \text { Clean Development Mechanism } \\ \text { HOMER } & \text { Hybrid Optimization Models of Energy } \\ & \text { Resources } \\ \text { CSR } & \text { Company Social Responsibility }\end{array}$

\section{Introduction}

As an increasing of load demand, scarcity of fossil fuel and higher penetration of GHGes effect such as increasing daily temperature, utilization of RER are rising drastically (Moradi and Abedini, 2012). DG is a technology giving opportunity to integrating RER into power system network (Gozel and Hocaoglu, 2009). From many researches, penetration of RER in the electrical power system, especially in the level

\footnotetext{
* Corresponding Author:

Email: woro_s2te_11@mail.ugm.ac.id
} 
distribution system give the positive impacts such as reduce power losses (Sohi et al., 2011), improve voltage profile (Al-Abri et al., 2011), avoid generators congestion (Khanabadi et al., 2011), enhancement of network stability (Al Abri et al., 2013), reduce concentration of GHG (Sohi et al., 2011), enhancement of power quality (Sheng et al., 2011), reliability of overall subsystem in power system (Prabha et al., 2012) and save installation cost of new transmission as a response of load growth demand (Sheng et al., 2011).

Penetration RER into power system should have considered many factors in planning to maximize advantages in the power system. The activity of penetrate RER in there is called generation GEP. GEP is defined determining type and optimal time to operate new renewable energy generation to supply load demand in the system beside keep reliability in the desired level in the long term horizon (Parsaeifard et al., 2010).

There are many factors need to be consider to penetrate RER in electrical power system. The aim of this paper is reviewing those factors when preparing, operating and evaluating electrical power system. The purpose of this review is giving the guideline for government, researcher, engineer and private sector to make policies to preparing hybrid power system-DGs.

\section{Review of Considered Factors to Penetrate Renewable Energy Resources in Electrical Power System}

\subsection{Size and site of DGs as a penetration of RER into distribution network}

Penetration of RER in the distribution network as DGs will bring many advantages for the power system. It will be happen if the size and site of DGs is determined by appropriately. The inappropriate of size and site will bring the reverse Impact for distribution network (Jamian, Mokhlis, et al., 2012). So, there is needed optimization of sizing and sitting of DGs in the distribution network. Those activities are done with many kinds; include optimization method and objective function. The last researches of optimization method for sizing and sitting of DGs are using heuristic method. It is because of the quality of solution both are in optimal site with corresponding size and time to convergence (Jamian, Aman, et al., 2012) (Soeprijanto and Abdillah, 2011). PSO and GA are the heuristic method often used to optimize size and site of DGs (Gomez et al., 2010) (Sookananta et al., 2010) (Prabha et al., 2012) (Sedighi et al., 2010) (Ismail et al., 2011) (Nabavi et al., 2011) (Gonzalez et al., 2012) (Haghdar and Shayanfar, 2010).

Sometimes, to improve quality of optimal global solution in size and site of DGs is done modification and hybridization of heuristic methods to other methods. EPSO, REPSO (Jamian, Mokhlis, et al., 2012), IPSO (Jamian, Aman, et al., 2012), Discrete PSO (Gonzalez et al., 2012), CRPSO (Mistry et al., 2012), NSGA-II (Zamani and Irving, 2012), IAGA (Lili et al., 2010), AGA (Liu, Bao, et al., 2011), QGA (Aryani et al., 2011) and multiobjective GA (Veerapen and Ah King, 2012) are the kind of modified heuristic method which is often used for optimization of sizing and sitting of DGs. Those methods are obtained coming from differentiated of PSO and GA. In the other hand, hybrid method is the combination between heuristic method and heuristic method or the other kind of method. Hybrid PSO-GA (Moradi and Abedini, 2012), PSO-ANOVA (AlRashidi and AlHajri, 2011), T2FBPSOM (Soeprijanto and Abdillah, 2011), PSO-HBMO (Afzalan et al., 2012) and (Liu, Wen, et al., 2011) are the hybrid optimization method for sizing and sitting of DGs.

The objective functions which are often consider in the optimization in line with purposes of installing DGs in the distribution network.

Finally, optimization method is determining the appropriate size and site of DGs in the distribution network. The appropriate optimization method should to be selected for this activity. The development of technology computing include the availability of supercomputer make the time to convergence is not fully problem.

\subsection{The type and energy potency of RER}

Type and energy potency of RER should be considered in the GEP with long-term horizon. There are many kinds of RER, i.e., solar, wind, biomass, tidal, diesel, gas turbine, fuel cell (K. et al., 2012) (Moniruzzaman and Hasan, 2012) etc whose potencies as DG. The type of those can be divided into 2 kinds, i.e., intermittent RER and non-intermittent RER. Diesel and gas turbine are the kind of non-intermittent RER. These sources are used as backup of utilization of intermittent 
RER (Kabouris and Kanellos, 2010). The availability of them is used as controller of voltage, frequency and power output (Jianye and Jia, 2012). Solar and wind are the kind of intermittent RER (Solanki et al., 2011). Then, not all the RER produce the kind same of power; solar can not produce reactive power but wind can produce both active and reactive power (Bianu and Frant, n.d.). The availability of DFIG makes the utilization of wind power increase drastically. It is caused the capability of DFIG to produce constant frequency and nominal output power (Yao et al., 2009).

The availability of micro-grid platform have been supported the variant of RER in the integration of RER in the distribution network. Micro-grid is proposed by R.H. Lasseter in 2001. It is consisted by the distributed source such as solar, wind, biomass, energy storage facilities, energy transformation facilities, monitoring and protecting facilities and relative loads. It is an isolating system which could realize the self-control, protection and management. The micro-grid could be operating connected with the distribution system, or isolated with the grid. In micro-grid, the electricity users need is provided by the RER. Micro-grid could be controlled easily and is connected with the distributed grid. When there is fault happening in upstream network, micro-grid could operate isolated with the main grid (Hongen et al., 2011).

Energy potency is the main factor for extraction of RER. It is depending on the geographical locations of utilization for utilization of solar and wind energy. The other RER such as biomass is depending on the heavy potency. In the other hand, it is suggested that collect the resource of biomass energy to one place so the extraction can be done effectively because of only needed an installation. For the kind of RER like tidal, the considering factors for utilization are coming things, such as energy potency and technology for extraction (tidal power, tidal fence and tidal turbine) (Twidell and Weir, 2006).

\subsection{Load Demand}

Load demand is purpose of extending of power system. Increasing load demand causes the extending network. Anticipating load demand for planning of power system in long/short-time horizon is needed forecasting. There are many forecasting method to predict load demand. To anticipate in-accuracy load demand, load forecasting in a region is divided into subforecasting for many sub-regions (Fan et al., 2009). The short-term forecasting involves weather data in every sub-region. SVR for day-ahead operation and market are used in this load forecasting. In the other hand, a new ANN is used to solve the high forecasting errors in case of rapid temperature changes (Osman et al., 2009). Then, fuzzy method is combined with ANN in hourly basis load forecasting (Sachdeva and Verma, 2008). Solving uncertainty factors in load forecasting, a new load forecasting model is given. The model uses pattern recognition which obtains input set belong to multilayered fed-forward neural network and artificial neural network in which back propagation learning algorithm is used to train samples (Dai and Wang, 2007). Hybrid PSO-BP is used to load forecasting (He and $\mathrm{Xu}, 2012$ ). PSO is used to control parameters in BP. Finally, ANN uses to forecast load demand in hourly basis (Tasre et al., 2012).

Although the load forecasting are done based short term horizon but the result can be used in GEP (Anwari et al., 2011) (Kansara and Parekh, 2011).

\subsection{Economical factor}

Economical factor is a close factor toward technical factor in GEP. It is because of generating consideration on environmental issues, such as GHG. CBA is a popular tool to analyze between technical and environmental factors. Congestion factor is one of the technical issues which is considered here (Papaemmanouil et al., 2010). Every RER technologies have a unique behavior on economical side. So, the kind of RER must be considered in order to merit the other factors, i.e., investment plans, market prices, demand growth, operation cost and the uncertainties factors (Pereira and Saraiva, 2009). Compared with fossil fuel, it is expensive to transport renewable energy for a long distance. Beside that, unstable characteristic is one of the weakness factor which must be known by analyst, investors and policy makers to find out how to take full use of current and emerging technologies to support the development of renewable energy (Ding and Somani, 2010). To manage their amount of investment, GENCO applies IRR index. Some uncertainty factors, such as electricity prices over the planning horizon, fuel price volatility for hybrid generation system, power demand and intermittently of RER (Alishahi et al., 2012) should be considered. It are 
done because these factors influence the IRR (Sharma and Bhattacharya, 2009). Incentives will be given to DG companies to support renewable resources besides developing DG implementations and incentive treatment for installing high-technology solutions for emissions reduction. Beside incentives, GENCO will give penalty due to delay in construction and delivery of power plant and penalty for emissions (Parsaeifard et al., 2010).

\subsection{Community Development}

CD is a much used word is readily attached to renewable energy projects, initiatives and policies as part of the discursive politics of modern governance (Walker and Wright, 2008). CD is agreed have capability to increase advantages in renewable energy projects because high participation in sustainability energy. The sustainability energy can be achieved by acceptance of renewable energy, awareness of renewable and sustainable energy technologies and issues, uptake of low carbon technologies and sustainable/proenvironmental behaviors (Rogers et al., 2012). It is done because top-down developments projects can not guarantee solve sustainability issues. In the other hand, CD needs institutional support for successfully implementation (Rogers et al., 2008). But, the trust between local people and groups that take projects determine the successfully of this project too (Walker et al., 2010). This implementation is very important to do because CDM with sustainable development aspect under Kyoto Protocol can be used to alleviate poverty for rural areas and not increase by a focus on renewable energy technologies (Lloyd and Subbarao, 2009). It is suitable for development country with heavy poverty of people living and depending on fossil fuel.

\section{Discussion}

According to Ministry of Energy and Mineral Resources in vision $25 / 25$, utilization of renewable energy is increased to $25 \%$ of the total national energy consumption by 2025. This vision exceeds the target that was set by the Government earlier in the Presidential Regulation No. 5 year 2006 concerning on National Energy Policy, which only targeted of $17 \%$ for new and RER share in the national energy mix (Sukarna, 2011). Because of DG's technology availability, penetration RERs has possibility as solution for the conditions, i.e., load demand growth, scarcity of fossil fuel and penetration of GHG emissions.

Integrating DGs in the distribution network is included GEP. In the other hand, GEP is a complex problem which is the successfully of them influenced by many factors. Furthermore, optimization of the involved factors is needed in there.

DG is good idea for integrating RER into electrical power system, especially distribution network. Actually, existing of distribution system is not prepared to receive new generation installations. But, laying the existing condition in planning will give the disadvantages for the power system. To solve the problem, it is need optimization in sizing and sitting of DGs. Many optimization methods are used to optimization in there. The main problem in this activity is how to find the optimization method whose good quality both are in the quality of optimal global solutions and time to convergence. Heuristic methods are often used to solve the problem. Sometimes, to get better performance, heuristic method is hybrid with other method; both are heuristic method and nonheuristic method. The result shows that hybrid method gives better performance than mono-method. Moreover, hybrid method coming from 2 heuristic methods gives the better performance than hybrid method coming heuristic method and non-heuristic method. But complexity in programming is a challenge in this implementation.

Type and energy potency of RER are the factors considered in the planning. Although utilization of fossil fuel bring the negative impacts, its resource is important to support utilization of RER. It is done to handle intermittently of RER such as solar and wind. With the optimal hybrid of the resources, the stability of power system can be increased or kept in the desired level. Some qualitative issue related utilization of RER, such as biomass and tidal should be considered in the planning.

Micro-grid is a platform to penetrate RER and fossil fuel in the distribution system. This platform can guarantee the stability and security of the system because of that capability to work in islanded or grid connected mode.

The next factor which is important in the GEP is load demand. The accuracy of load demand determine the successfully of GEP. To get accuracy load demand, many researches focus in the load forecasting. Heuristic method and approximated method are used in those 
researches. Although the basis calculation is the hourly, the result can be used in the GEP which usually in longterm horizon like in software HOMER.

Economical factor is a close factor for technical factor in the GEP. Investment, operation and maintenance are the main economical factor for GEP. But, as an increasing of GHG emissions because of fossil fuel burning, the incentive is included in the GEP. For deregulating policies, GENCO will give the DG companies will give DG companies with incentive which is used RER as DGs. Because of urgently needed of DGs coming from RER, GENCO will give penalty for the delay of building of them.

The important factor for successfully of renewable energy project is CD. With high participation of people in the project, the sustainability energy can be achieved. Although the explanation on CD focuses in rural people, but the successfully of renewable energy projects is determined by the cooperation of government and groups whose the project or DG companies.

\section{Conclusion}

This paper focuses on the considered factors in penetration of RER in electrical power system. DG technology gives the opportunity to penetration of RER. For advance, micro-grid gives more benefit to implementation of the penetration. Size and site of DGs, load demand, economical factor which is related to environmental factor and the feasibility project and community development are given as considered factors in GEP.

\section{Table 1}

Summary of considered factors for integrating of RERs as DGs in the distribution network

\begin{tabular}{|c|c|}
\hline Considered factors & Policies/technical suggestions \\
\hline $\begin{array}{l}\text { Size and site of DGs } \\
\text { as penetration of } \\
\text { RERs in the } \\
\text { distribution network }\end{array}$ & $\begin{array}{l}\text { - Selecting the optimal optimization } \\
\text { method for determining size and site of } \\
\text { DGs as RERs in the distribution } \\
\text { network. } \\
\text { - Preparing supercomputer for these } \\
\text { activities. } \\
\text { - Involving the policy maker in many } \\
\text { fields, i.e., economic, environment, } \\
\text { engineering, social, financial; delegation } \\
\text { of private sector; and researcher in } \\
\text { software engineering to included } \\
\text { important factors to be considered in } \\
\text { the optimization process. }\end{array}$ \\
\hline
\end{tabular}

\begin{tabular}{|c|c|}
\hline $\begin{array}{l}\text { The type and energy } \\
\text { potency of RERs }\end{array}$ & $\begin{array}{l}\text { - Mapping renewable energy potency in } \\
\text { around of distribution network. } \\
\text { - Optimize the electrical machine which } \\
\text { will be used in the electrical energy } \\
\text { conversion whether induction } \\
\text { generator, synchronous generator or } \\
\text { doubly-fed induction generator. } \\
\text { - Involving the policy maker in many } \\
\text { fields, i.e., economic, environment, } \\
\text { engineering, social, financial; delegation } \\
\text { of private sector; and researcher in } \\
\text { software engineering to included } \\
\text { important factors to be considered in } \\
\text { the integrating process. } \\
\text { - Mapping sustainability capability for } \\
\text { communities about their } \\
\text { comprehensively knowledge on type of } \\
\text { renewable energy. }\end{array}$ \\
\hline Load demand & $\begin{array}{l}\text { - Selecting the optimal forecasting } \\
\text { method for determining load demand } \\
\text { until the end of project lifetime. } \\
\text { - Preparing supercomputer for these } \\
\text { activities. } \\
\text { - Involving the policy maker in many } \\
\text { fields, i.e., economic, environment, } \\
\text { engineering, social, financial; delegation } \\
\text { of private sector; and researcher in } \\
\text { software engineering to included } \\
\text { important factors to be considered in } \\
\text { the forecasting process. }\end{array}$ \\
\hline Economical factor & $\begin{array}{l}\text { - Inviting the investors to establish } \\
\text { renewable energy projects in Indonesia } \\
\text { by giving the incentive and penalty for } \\
\text { them. Incentive is given for investor } \\
\text { who can accelerate of the establishment } \\
\text { and penalty for the delay of building of } \\
\text { them. } \\
\text { - Making an optimal feed-in tariff for } \\
\text { selling of electrical energy coming from } \\
\text { renewable energy to support renewable } \\
\text { energy business. } \\
\text { - Encouraging of the activities of CSR of } \\
\text { private companies in Indonesia to } \\
\text { participate in the integration of RERs as } \\
\text { DGs in the distribution network. }\end{array}$ \\
\hline $\begin{array}{l}\text { Community } \\
\text { development }\end{array}$ & $\begin{array}{l}\text { - Inviting the investors to establish } \\
\text { renewable energy projects in Indonesia } \\
\text { by giving the incentive and penalty for } \\
\text { them. Incentive is given for investor } \\
\text { who can accelerate of the establishment } \\
\text { and penalty for the delay of building of } \\
\text { them. } \\
\text { - Making an optimal feed-in tariff for } \\
\text { selling of electrical energy coming from } \\
\text { renewable energy to support renewable } \\
\text { energy business. } \\
\text { - Encouraging of the activities of CSR of } \\
\text { private companies in Indonesia to } \\
\text { participate in the integration of RERs as }\end{array}$ \\
\hline
\end{tabular}


DGs in the distribution network.

- Integrating the awareness of renewable energy utilization to lower level education until higher level education (kindergarten school to university).

\section{References}

Afzalan, M., Taghikhani, M.A., Sedighizadeh, M., 2012. Optimal DG Placement and Sizing with PSO\&HBMO Algorithms in Radial Distribution Networks. Conference on Electrical Power Distribution Networks (EPDC) 1-6.

Al Abri, R.S., El-Saadany, E.F., Atwa, Y.M., 2013. Optimal Placement and Sizing Method to Improve the Voltage Stability Margin in a Distribution System Using Distributed Generation. IEEE Transactions on Power Systems 28, 326-334.

Al-Abri, R.S., El-Saadany, E.F., Atwan, Y.M., 2011. Distributed Generation Placement and Sizing Method to Improve the Voltage Stability Margin in a Distribution System. 2nd International Conference on Electric Power and Energy Conversion Systems (EPECS) 1-7.

Alishahi, E., Moghaddam, M.P., Sheikh-El-Eslami, M.K., 2012. A system dynamics approach for evaluating the optimum value of reliability-based incentive mechanism for wind generation in GEP. IEEE Power and Energy Society General Meeting 18.

AlRashidi, M.R., AlHajri, M.F., 2011. Optimal planning of multiple distributed generation source in distribution networks: A new approach. Energy Conversion and Management 52, 3301-3308.

Anwari, M., Rashid, M.I.M., Hui, H.I., Yee, T.W., Wee, C.K., 2011 Photovoltaic Power System Simulation for Small Industry Area. International Conference on Electrical, Control and Computer Engineering 263-268.

Aryani, N.K., Abdillah, M., Negara, I.M.Y., Soeprijanto, A., 2011. Optimal Placement and Sizing of Distributed Generation using Quantum Genetic Algorithm for Reducing Losses and Improving Voltage Profile. Region 1 - Conference TENCON 2011.

Bianu, A., Frant, S., n.d. A Chronological Model for Reliability Calculation in an Electric Generation System and Its Importance in Long Term System Planning 215-218.

Dai, W., Wang, P., 2007. Application of Pattern Recognition and Artificial Neural Network to Load Forecasting in Electric Power System. Third International Conference on Natural Computation (ICNC).

Ding, J., Somani, A., 2010. A Long-Term Investment Planning Model for Mixed Energy Infrastructure Integrated with Renewable Energy. IEEE Green Technologies Conference 1-10.

Fan, S., Methaprayoon, K., Lee, W.-J., 2009. Multiregion Load Forecasting for System With Large Geographical Area. IEEE Transactions on Industry Applications 45, 1452-1459.

Gomez, M., Lopez, A., Jurado, F., 2010. Optimal placement and sizing from standpoint of the investor of Photovoltaics GridConnected Systems using Binary Particle Swarm Optimization. Applied Energy 87, 1911-1918.

Gonzalez, M.G., Lopez, A., Jurado, F., 2012. Optimization of distributed generation systems using a new discrete PSO and OPF. Electric Power and Energy Systems 84, 174-180.

Gozel, T., Hocaoglu, M.H., 2009. An analytical method for the sizing and siting of distributed generators in radial systems. Electric Power System Research 79, 912-918.

Haghdar, K., Shayanfar, H.A., 2010. Optimal Placement and Sizing of DG and Capacitor for the Loss Reduction via Methods of Generalized Pattern Search and Genetic Algorithm. AsiaPacific Power and Energy Engineering Conference (APPEEC) 1-4.

He, Y., Xu, Q., 2012. Short-term Power Load Forecasting Based on Selfadapting PSO-BP Neural Network Model. Fourth International Conference on Computational and Information Sciences 1096-1099.

Hongen, T., Bo, W., Dichen, L., Suxuan, G., 2011. Analysis of distributed generation system based on micro-grid and its impaction on voltage distribution. IEEE.

Ismail, M., Chen, M.-Y., Li, X., 2011. Optimal planning for power distribution network with distributed generation in Zanzibar Island. International Conference on Electrical and Control Engineering (ICECE) 266-269.

Jamian, J.J., Aman, M.M., Mustafa, M.W., Jasmon, G.B., Mokhlis, H., Bakar, A.H.A., Abdullah, M.N., 2012. Optimum multi DG units placement and sizing based on voltage stability index and PSO. 47th International Universities Power Engineering Conference (UEPEC) 1-6.

Jamian, J.J., Mokhlis, H., Abdullah, M.N., 2012. Comparative Study on Distributed Generator Sizing Using Three Types of Particle Swarm Optimization. Third International Conference on Intelligent Systems Modelling and Simulation 131-136.

Jianye, L., Jia, L., 2012. Model and control of a DC microgrid made up by solar and wind. International Conference on Computer Science and Electronics Engineering 437-441.

K., B., S., K., Vijayakumar, P., 2012. Comparative Study of Hybrid Photovoltaic-Fuel Cell System/Hybrid Wind-Fuel Cell System for Smart Grid Distributed Generation System. International Conference on Emerging Trends in Science, Engineering and Technology 462-466.

Kabouris, J., Kanellos, F.D., 2010. Impacts of Large-Scale Wind Penetration on Designing and Operation of Electric Power Systems. IEEE Transactions on Sustainable Energy 1, 107114.

Kansara, B.U., Parekh, B.R., 2011. Modelling and Simulation of Distributed Generation System Using HOMER Software. International Conference on Recent Advancements in Electrical, Electronics and Control Engineering 328-332.

Khanabadi, M., Doostizadeh, M., Esmaeilian, A., Mohseninezhad, M., 2011. Transmission Congestion Management through Optimal Distributed Generation's Sizing and Placement. 10th International Conference on Environment and Electrical Engineering (EEEIC) 1-4.

Lili, X., Xiaoyan, Q., Xiwen, W., Xingyuan, L., 2010. Research of Distribution Generation Planning in Smart Grid Construction. Asia-Pacific Power and Energy Engineering Conference (APPEEC) 1-4.

Liu, L., Bao, H., Liu, H., 2011. Siting and sizing of distributed generation based on the minimum transmission losses cost. IEEE Power Engineering and Automation Conference (PEAM) $22-25$.

Liu, Z., Wen, F., G, L., 2011. Optimal Siting and sizing of Distributed Generators in Distribution Systems Considering Uncertainties. IEEE Transactions on Power Delivery 25412551. 
Lloyd, B., Subbarao, S., 2009. Development challenges under the Clean Development Mechanism (CDM) - Can renewable energy initiatives be put in place before peak oil? Energy Policy 37 237-245.

Mistry, K., Bhavsar, V., Roy, R., 2012. GSA based Optimal Capacity and Location Determination of Distributed Generation in Radial Distribution System for Loss Minimization. 11th International Conference on Environment and Electrical Engineering (EEEIC) 513-518.

Moniruzzaman, M., Hasan, S., 2012. Cost analysis of PV/Wind/Diesel/Grid connected Hybrid Systems. IEEE/OSA/IAPR International Conference on Informatics, Electronics \& Vision 727-730.

Moradi, M.H., Abedini, M., 2012. A combination of genetic algorithm and particle swarm optimization for optimal DG location and sizing in distribution system. Electrical Power and Energy Systems 34, 66-74.

Nabavi, S.M.H., Hajforoosh, S., Masoum, M.A.S., 2011. Placement and Sizing of Distributed Generation Units for Congestion Management and Improvement of Voltage Profile using Particle Swarm Optimization. PES Innovative Smart Grid Technologies Asia (ISGT) 1-6.

Osman, Z.H., Awad, M.L., Mahmoud, T.K., 2009. Neural Network Based Approach for Short-Term Load Forecasting. IEEE 1-8.

Papaemmanouil, A., Tuan, L.A., Andersson, G., Bertling, L., Johnsson, F., 2010. A cost-benefit analysis of transmission network reinforcement driven by generation capacity expansion. IEEE Power and Energy Society General Meeting 1-8.

Parsaeifard, A.H., Manbachi, M., Kopayi, M.B.A., Haghifam, M.R., 2010. A market-based generation expansion planning in deregulated environment based on distributed generations development. IEEE 11th Probabilistic Methods Applied to Power Systems (PMAPS) 677-684

Pereira, A.J.C., Saraiva, J.T., 2009. A decision support tool for generation expansion planning in competitive markets using System Dynamics models. IEEE Bucharest Power Tech Conference 1-7.

Prabha, D.R., Mageshvaran, R., Raghunath, E., Raghuram, G., 2012 Determining the Optimal Location and Sizing of Distributed Generation Unit using Particle Swarm Optimization Algorithm. International Conference on Computer Communication and Informatics (ICCCI) 1-7.

Rogers, J.C., Simmons, E.A., Convery, I., Weatherall, 2012. Social impacts of community renewable energy projects: finding from a woodfuel case study. Energy Policy 42, 239-247.

Rogers, J.C., Simmons, E.A., Convery, I., Weatherall, A., 2008. Public perceptions of opportunities for community-based renewable energy projects. Energy Policy 36, 4217-4226.

Sachdeva, S., Verma, C.M., 2008. Load Forecasting using Fuzzy Methods. IEEE

Sedighi, M., Igderi, A., Parastar, A., 2010. Sitting and sizing of Distributed Generation in distributed network to improve of several parameters by PSO algorithm. IPEC 1083-1087.

Sharma, D., Bhattacharya, K., 2009. A planning model for investor firms in the generation sector and financial analysis. IEEE Power \& Energy Society General Meeting 1-7.

Sheng, S., Tian, Y., Zou, Y., Wei, Z., 2011. A simplified PSO algorithm for sizing and siting distributed generation. International
Conference on Materials for Renewable Energy \& Environment (ICMREE) 1529-1533.

Soeprijanto, A., Abdillah, M., 2011. Type 2 Fuzzy Adaptive Binary Particle Swarm Optimization for Optimal Placement and Sizing of Distributed Generation. 2nd International Conference on Instrumentation, Communications, Information Technology, and Biomedical Engineering (ICICBME) 233-238.

Sohi, M.F., Shirdel, M., Javidaneh, A., 2011. Applying BCO algorithm to solve the optimal DG placement and sizing problem. 5th International Power Engineering and Optimization Conference (PEOCO) 71-76.

Solanki, A., Montoya, L.F., Fu, Q., Nasiri, A., Bhavaraju, V., Abdallah, T., $\mathrm{Yu}$, D., 2011. Managing Intermittent Renewables in a Microgrid. IEEE 1-6.

Sookananta, B., Kuanprab, W., Hanak, S., 2010. Determination of the optimal location and sizing of Distributed Generation using Particle Swarm Optimization. International Conference on Electrical Engineering/Electronics Computer Telecommunications and Information Technology (ECTICON) 812-822.

Sukarna, D., 2011. Opportunity and Challenge in The Development of New and Renewable Energy.

Tasre, M.B., Ghate, V.N., Bedekar, P.P., 2012. Input Vector Comparison for Hourly Load Forecast of Small Load Area Using Artificial Neural Network. International Conference on Communication Systems and Network Technologies 254258.

Twidell, J., Weir, T., 2006. Renewable Energy Resources, Second ed. Taylor \& Francis, New York, USA.

Veerapen, S., Ah King, R.T.F., 2012. Integrating distributed energy resources in the electrical grid considering resource variability for reliable power planning. IECON 2012 - 38th Annual Conference on IEEE Industrial Electronics Society 1356-1361.

Walker, G., Wright, P.D., 2008. Community renewable energy: What shloud it mean? Energy Policy 36, 497-500.

Walker, G., Wright, P.D., Hunter, S., High, H., Evans, B., 2010. Trust and community: Exploring the meanings, contexts and dynamics of community renewable energy. Energy Policy $38,2655-2663$.

Yao, X., Liu, S., Xiao-Dong, W., Chang-chun, G., Xing, Z., Jiang, H.-L., 2009. Doubly-fed induction generator control for variablespeed wind power generation system. International Conference on Mechatronics and Automation 855-859.

Zamani, I., Irving, M., 2012. A novel approach to distributed energy resource planning using NSGA-II. 47th International Universities Power Engineering Conference (UEPEC) 1-5. 